\title{
PECULIARITIES OF DEVELOPMENT OF UKRAINIAN REPAIR HEIFERS RED-AND-WHITE AND BLACK-AND-WHITE DAIRY BREEDS IN FARMS OF SUMY REGION
}

\author{
Khmelnychyi Serhii Leontievych \\ Ph.D. of Agricultural Sciences, Senior Lecturer \\ Sumy National Agrarian University \\ ORCID: 0000-0003-2352-3317 \\ E-mail: serhiokh@ukr.net
}

Karpenko Bogdan Mykolayovych Graduate student specialty 204-TPPLP

Sumy National Agrarian University ORCID: 0000-0002-9942-5863 E-mail: karpenkobogdan95@gmail.com

Bardash Dmitryi Alexandrovich Graduate student specialty 204-TPPLP

Sumy National Agrarian University ORCID: 0000-0002-9368-2324 E-mail: d.bardash@ukr.net

The leading farms of the Sumy region studied the peculiarities of the growth of repair heifers of Ukrainian Black-and-White (PZ PE "Burynske") and Red-and-White (LLC "Mlynivskyi complex") dairy breeds. The absolute and relative indicators of live weight gain of heifers in the age dynamics from birth to 18 months of age were studied. Heifers of the Ukrainian Red-and-White dairy breed $(36.2 \mathrm{~kg})$ were the best in terms of live weight at birth in comparison with the peers of the Ukrainian Black-and-White dairy breed $(33.9 \mathrm{~kg})$. Their advantage persisted during the 18-month growing period. Repair heifers of the Ukrainian Red-and-White dairy breed at the final stage of development with an average live weight of $414.2 \mathrm{~kg}$ exceeded the peer of the Ukrainian Black-and-White dairy breed with a highly reliable difference of $15.5 \mathrm{~kg}(P<0.001)$. The development of repair heifers of both breeds within the obtained live weight indicators ensured their increase at the time of mating age at the level of $76-80 \%$ of the minimum target standards set for the first-born cows of dairy type of the created breeds. The average daily gains in live weight in the milk period averaged $810.4 \mathrm{~g}$ in heifers of the Ukrainian Black-and-White dairy breed, and $847.3 \mathrm{~g}$ in their peers of the Ukrainian Red-and-White dairy breed, the highest in the animals of the Ukrainian Red-and-White dairy breed herd LLC "Mlynivsky complex". The results of research showed that with the creation of appropriate conditions for feeding and keeping repair heifers of Ukrainian Black-and-White and Red-andWhite dairy breeds were capable of high growth intensity.

Key words: Ukrainian Black-and-White, Ukrainian Red-and-White, repair heifers, live weight.

DOI: https://doi.org/10.32845/bsnau.lvst.2020.2.3

In-depth selection of dairy cattle was impossible without a careful assessment of breeding animals at an early age and during their individual development. In this aspect, the first method of morphological studies of animal development involved accounting for their live weight. The results of these observations were indicators of animal growth, which characterize the intensity of metabolic processes occurring in the body [7].

According to advanced practical and scientific experience, intensive growth and development of repair heifers of dairy cattle significantly determined the desired body type of animals in adulthood and, as a result, allowed to realize the genetic potential of milk productivity of cows determined by ancestral heredity $[2,4,8,19,20,22]$.

Genetically programmed productivity can be realized only under favorable conditions of growing, care and use of animals $[9,12,23]$. It was found that the growth rate of heifers of different genotypes was closely related to the level of milk productivity. Reducing the intensity of growing heifers in the period up to 18 months and the first calving did not allow animals to fully realize their genetic potential of milk productivity [1, 15].

From the production point of view, precocity of repair heifers reduced the unproductive period of rearing from birth to calving, from the selection - accelerated the process of assessing breeding bulls for offspring quality and promoted intensive reproduction of the herd, which ultimately significantly determined the profitability of dairy farming $[6,13]$. In addition, it was found that the value of live weight of heifers at the end of the rearing period and the beginning of the mating age, positively correlated with the subsequent milk productivity during the first and second lactations [3, 5, 17, 18, 25]. The obtained results of research $[21,24]$ show that for determining the optimal time of the first insemination was more important not age, but live weight and general development of animals, as insemination of heifers with low live weight in both early and late age leading to deterioration of their economic value.

According to research [10] of the Ukrainian Red dairy breed, it was found that cows realized their highest milk productivity for the first, third and best lactation $(6242,7465$ and 7916 $\mathrm{kg}$ of milk, respectively) under the condition of their first insemination at 14.5-15 months of age and their achievement of live weight $420-439 \mathrm{~kg}$.

It was found that the highest level of milk productivity of Вісник Сумського національного аграрного університету 
first-born cows (over 8.0 thousand $\mathrm{kg}$ of milk in 305 days of completed lactation) was achieved in herds where the average daily gain of heifers in the age period of $0-12$ months brought to the level of 820-850 g. Compliance with these parameters was a prerequisite for the formation of highly productive dairy herds, in which increasing the efficiency of milk production will be ensured by reducing unproductive costs for maintenance of young animals and increasing net income from large volumes of milk [11].

The aim of the research was to study the peculiarities of growth and development of repair heifers of Ukrainian dairy breeds in the Sumy region.

Materials and methods. The experimental base for the research were herds of enterprises for breeding Ukrainian Redand-White dairy breed LLC "Mlynivskyi complex" of Romenskyi branch of Sumy region and Ukrainian Black-and-White dairy breed of breeding farm PE "Burynske" of Podlisnivsky branch of Sumy district.

The dynamics of live weight of heifers was determined by monthly weighing. The absolute increase in live weight (D) for individual age periods of the study was determined by the formula:

$D=W_{t}-W_{0}$; де $W_{t} i W_{0}$ - final and initial live weight, $\mathrm{kg}$.

The absolute average daily gain was determined by the formula:

$$
\mathrm{D}=\frac{\mathbf{W t}-\mathbf{W o}}{\mathbf{t}_{2}-\mathbf{t}_{1}} ;
$$

where $\mathrm{W}_{\mathrm{t}}$ and $\mathrm{W}_{0}$ - live weight at the end and beginning of the period, $\mathrm{kg}$;

$t_{2} i t_{1}-$ age at the end and beginning of periods, days.
The relative growth intensity $(K)$ of repair heifers was determined by the formula of S. Brodi (quoted by K. B. Svechin, [16]):

$$
K=\frac{(W t-W o) \times 100}{(W t+W o): 2}
$$

Statistical processing of experimental data was performed according to the formulas given by E. K. Merkur'eva, [4] on a PC using software.

Research results. Estimation of repair heifers of experimental breeds by live weight gain in age dynamics from birth to eighteen months of age indicated satisfactory conditions for their cultivation in controlled farms, table. 1.

A comparative analysis of the research results showed that the best in live weight at birth were heifers of Ukrainian Red-and-White dairy breed LLC "Mlynivskyi complex" (36.2 kg) compared with peers in the herd of Ukrainian Black-and-White dairy breed PE "Burynske" (33, $9 \mathrm{~kg})$ with a high reliability difference of $2.3 \mathrm{~kg}(P<0.001)$ in favor of the former.

During the 18-month rearing period, the repair heifers in the herd of Mlynivskyi Complex LLC were significantly better than the peers in the herd of PE Burynske. At the final stage of cultivation with an average live weight of $414.2 \mathrm{~kg}$, they exceeded their peers with a highly significant difference of $15.5 \mathrm{~kg}(P$ $<0.001$ ).

The development of live weight parameters obtained in the course of research ensured its increase in repair heifers during the mating season at the level of $76-80 \%$ of the minimum target standards set for the first-born cows of dairy type of created breeds $(530-550 \mathrm{~kg})$

\section{Characteristics of repair heifers of Ukrainian dairy

\begin{tabular}{|c|c|c|c|c|}
\hline \multirow{3}{*}{$\begin{array}{l}\text { Age of animals, } \\
\text { months }\end{array}$} & \multicolumn{4}{|c|}{ Breed } \\
\hline & \multicolumn{2}{|c|}{ Ukrainian Black-and-White dairy $(n=22)$} & \multicolumn{2}{|c|}{$\begin{array}{c}\text { Ukrainian Red-and-White } \\
\text { dairy }(n=24)\end{array}$} \\
\hline & $\mathrm{x} \pm$ S.E., $\mathrm{kg}$ & $\mathrm{Cv}, \%$ & $\mathrm{x} \pm$ S.E., $\mathrm{kg}$ & $\mathrm{Cv}, \%$ \\
\hline Newborns & $33,9 \pm 0,14$ & 13,5 & $36,2 \pm 0,17$ & 12,3 \\
\hline 3 & $109,1 \pm 0,28$ & 14,2 & $118,7 \pm 0,48$ & 13,6 \\
\hline 6 & $181,4 \pm 0,69$ & 15,9 & $190,4 \pm 0,85$ & 14,2 \\
\hline 9 & $247,7 \pm 0,78$ & 14,7 & $254,7 \pm 1,05$ & 13,8 \\
\hline 12 & $298,8 \pm 1,04$ & 16,1 & $317,3 \pm 0,98$ & 15,7 \\
\hline 15 & $349,6 \pm 1,11$ & 15,2 & $368,2 \pm 1,14$ & 16,2 \\
\hline 18 & $398,7 \pm 1,29$ & 14,8 & $414,2 \pm 1,08$ & 15,5 \\
\hline First insemination & $414,8 \pm 1,67$ & 16,3 & $422,5 \pm 1,78$ & 17,2 \\
\hline First calving & $537,4 \pm 1,68$ & 17,4 & $554,4 \pm 1,86$ & 16,8 \\
\hline
\end{tabular} Breeds by live weight in age dynamics}

At the time of the first fertile insemination, repair heifers of both breeds corresponded in live weight to the parameters of the desired type with higher results in animals of the Ukrainian Red-and-White dairy breed in the herd of Mlynivskyi Complex LLC. The interbreed difference was highly reliable in favor of the latter $-7.7 \mathrm{~kg}(P<0,001)$. A similar situation developed in animals at the age of the first calving with an advantage of the Ukrainian Red-and-White dairy breed by $17 \mathrm{~kg}(\mathrm{P}<0.001)$.

In the process of growing repair heifers of dairy cattle should take into account the limits of the intensity of their rearing, as exceeded or insufficient level leads to a decrease in milk productivity [25]. The recommended norms of average daily gains for the period of rearing up to 18 months of age for obtaining cows of dairy cattle with a live weight of $500 \mathrm{~kg}$ were $650 \mathrm{~g}$, and $600 \mathrm{~kg}$, respectively, - $700 \mathrm{~g}$.
Intensive development of calves during the milk period, which lasted from birth to six months of age, was crucial. During this period, it was necessary to use the existing biological pattern of individual development as a high energy of growth in the first months of life, which provided a full-fledged young. The average daily gain of live weight in the period from birth to six months of age averaged $810.4 \mathrm{~g}$ in heifers of the Ukrainian Black-and-White dairy breed, and $847.3 \mathrm{~g}$ in their peers of the Ukrainian Red-and-White dairy breed (Table 2). The difference in favor of the latter $36.9 \mathrm{~g}$ was highly reliable $(P<0.001)$.

After a six-month rearing period and up to the mating age, the difference in average daily gains was higher in the animals of the Ukrainian Red-and-White dairy breed in the herd of Mlynivskyi Complex LLC. 
Average daily gains in live weight repair Heifers of Ukrainian dairy breeds

\begin{tabular}{|c|c|c|c|c|}
\hline \multirow{3}{*}{$\begin{array}{l}\text { Inter-age period, } \\
\text { months }\end{array}$} & \multicolumn{4}{|c|}{ Breed } \\
\hline & \multicolumn{2}{|c|}{ Ukrainian Black-and-White dairy $(n=22)$} & \multicolumn{2}{|c|}{ Ukrainian Red-and-White dairy $(n=24)$} \\
\hline & $x \pm$ S.E., $g$ & $\mathrm{Cv}, \%$ & $x \pm$ S.E., $g$ & $\mathrm{Cv}, \%$ \\
\hline $0-3$ & $826,4 \pm 1,45$ & 11,2 & $906,6 \pm 1,18$ & 10,8 \\
\hline $4-6$ & $794,5 \pm 1,62$ & 12,1 & $787,9 \pm 1,22$ & 11,3 \\
\hline $7-9$ & $728,6 \pm 1,13$ & 10,8 & $706,6 \pm 1,35$ & 11,7 \\
\hline $10-12$ & $561,5 \pm 0,97$ & 9,5 & $687,9 \pm 1,08$ & 9,5 \\
\hline $13-15$ & $558,2 \pm 0,88$ & 8,7 & $559,3 \pm 0,86$ & 8,4 \\
\hline $16-18$ & $539,6 \pm 0,91$ & 9,2 & $505,5 \pm 0,79$ & 7,8 \\
\hline $0-18$ & $665,7 \pm 0,84$ & 8,4 & $689,8 \pm 0,74$ & 7,5 \\
\hline
\end{tabular}

The obtained average daily gains of live weight of repair heifers of Ukrainian Black and Red-and-White dairy breeds for the whole growing period, respectively 665.7 and $689.8 \mathrm{~g}$, provided a satisfactory live weight of animals at the age of the first insemination and the first calving.

Absolute growth was to some extent an indicator of the intensity of growth of animals and it was widely used to control the growth of young animals at different stages of their ontogenesis. However, absolute growth cannot characterize the relative degree of intensity of the growth process of animals, because it did not reflect the relationship between the body weight of growing animal and the intensity of their growth.

To characterize the intensity of animal growth, we studied the relative growth of live weight of repair heifers in the three-month dynamics of postnatal ontogenesis (Table 3). At the same time insignificant interbreed variability on this trait was established.

Relative increase in repair calves by live weight, $\%$

\begin{tabular}{|c|c|c|c|c|}
\hline \multirow{3}{*}{$\begin{array}{l}\text { Inter-age period, } \\
\text { months }\end{array}$} & \multicolumn{4}{|c|}{ Breed } \\
\hline & \multicolumn{2}{|c|}{ Ukrainian Black-and-White dairy $(n=22)$} & \multicolumn{2}{|c|}{$\begin{array}{c}\text { Ukrainian Red-and-White } \\
\text { dairy }(n=24)\end{array}$} \\
\hline & $x \pm$ S.E., $\%$ & $\mathrm{Cv}, \%$ & $x \pm$ S.E., $\%$ & $\mathrm{Cv}, \%$ \\
\hline $0-3$ & $105,2 \pm 1,32$ & 14,8 & $106,5 \pm 1,44$ & 15,1 \\
\hline $4-6$ & $49,8 \pm 1,84$ & 15,3 & $46,4 \pm 1,52$ & 15,9 \\
\hline $7-9$ & $30,9 \pm 2,11$ & 16,4 & $28,9 \pm 1,65$ & 16,4 \\
\hline $10-12$ & $18,7 \pm 2,18$ & 16,7 & $21,9 \pm 1,84$ & 17,2 \\
\hline $13-15$ & $15,7 \pm 2,24$ & 17,4 & $14,9 \pm 2,13$ & 18,6 \\
\hline $16-18$ & $13,1 \pm 2,88$ & 18,7 & $11,8 \pm 2,24$ & 19,8 \\
\hline
\end{tabular}

According to K. B. Svechin [16], the most intensive growth was characterized by animals in the dairy period of their cultivation, and later this process slowed down. The indicators of relative development, which we obtained as a result of research, naturally coincided with the above statement.

The advantage of heifers in the herd of the enterprise "Mlynivskyi Complex" in comparison with peers of the breeding farm PE "Burynske" at the beginning of the rearing period (from birth to 3 months) was an unreliable difference of $1.3 \%$. In other age periods, the relative indicators between the breeds changed, and at the end of the growing period heifers of the Ukrainian Black-and-White dairy breed developed more inten- sively.

Thus, the results of experimental studies obtained in the process of studying the growth and development of repair heifers of Ukrainian Black and Red-and-White dairy breeds, indicate their ability under appropriate growing conditions to high growth intensity.

Conclusions. With the creation of appropriate growing conditions, repair heifers of Ukrainian Black-and-White and Redand-White dairy breeds were capable of high growth intensity, which ensured obtaining the desired level of live weight at the time of first insemination at an average of 414.8 and $422.5 \mathrm{~kg}$.

References:

1. Burkat, V. P., Melnyk, Yu. F., Yefimenko, M. la. [et al]. 2003. Prohramy selektsii porid [Breeds selection programs]. Rozvedennia i henetyka tvaryn, issue 37, pp. 3-22.

2. Hyl, M. I., Karatieieva, O. I. and Halushko I. A., 2017. Molochna produktyvnist holshtynskykh koriv zalezhno vid typu formuvannia yikh orhanizmu [Dairy productivity of Holstein cows depending on the type of formation of their organism]. «Molodyi vchenyi», no. 5(45), pp. 14-18.

3. Hordiichuk, N. M. and Pivtorak, Ya. I., 2008. Vplyv zhyvoi masy telychok ukrainskoi chervono-riaboi molochnoi porody pry narodzhenni na rist i rozvytok ta molochnu produktyvnist [Influence of heifers live weight of Ukrainian Red-and-White dairy breed at birth on growth and development and milk productivity]. Zbirnyk naukovykh prats Vinnytskoho derzhavnoho ahrarnoho universytetu, issue 34 , vol. 3 , pp. $57-60$

4. Denysiuk, O. V., 2015. Vplyv intensyvnosti formuvannia zhyvoi masy na molochnu produktyvnist koriv [Influence of intensity of live weight formation on milk productivity of cows]. Rozvedennia i henetyka tvaryn, issue 49, pp. 80-85.

5. Zabludovskyi, Ye. le. and Holubchyk, Yu. I., 2002. Realizatsiia produktyvnoho potentsialu molochnoi khudoby u zviazku z osoblyvostiamy rostu [Realization of productive potential of dairy cattle in connection with peculiarities of growth]. Rozvedennia $i$ 
henetyka tvaryn.: materialy naukovoi dyskusii "Rozvedennia silskohospodarskykh tvaryn za liniiamy" : mizhvidomchyi tematychnyi naukovyi zbirnyk IRHT. K. : Naukovyi svit, issue 36, pp. 61-63.

Kyiv: Urozhai.

6. Zubets, M. V., Siratskyi, Y. Z. and Danylkiv, Ya. N., 1993. Vyroshchuvannia remontnykh telyts [Growing of repair heifers].

7. Zubets', M. V., Burkat, V. P., Yefimenko, M. Ya. [et. al]. 1999. Burkat, V. P., ed. Henetyko-selektsiynyy monitorynh u molochnomu skotarstvi [Genetics and breeding monitoring in dairy cattle]. K.: Ahrarna nauka, 88.

8. Ivashkov, A., I. and Ryzhkova, L. Yu., 2006. Osobennosti rosta vysokoproduktivnykh korov [Features of the growth of highly productive cows]. Vestnik Rossiyskogo gosudarstvennogo agrarnogo zaochnogo universiteta, no. 1(6), pp. 121-122.

9. Ikoeva, L. P. and Khaeva, O. E., 2014 Vyrashchivanie remontnykh telok cherno-pestroy porody raznogo genotipa po golshtinskoy porode [Raising replacement heifers of a Black-and-White breed of different Holstein breed genotype]. Izvestiya Gorskogo gosudarstvennogo agrarnogo universiteta, vol. 51. no 3, pp. 133-141.

10. Iliashenko, H. D., 2017. Zviazok molochnoi produktyvnosti koriv z zhyvoiu masoiu i vikom pry pershomu osimeninni [Relationship between milk production of cows and live weight and age at first insemination]. Rozvedennia $i$ henetyka tvaryn, issue 54, pp. 45-50.

11. Kruhliak, O. V., 2018, Formuvannia vysokoproduktyvnykh molochnykh stad, yak chynnyk pidvyshchennia efektyvnosti vyrobnytstva moloka [Formation of highly productive dairy herds as a factor in increasing the efficiency of milk production]. Ekonomika $A P K$, no. 3, pp. 24-31.

12. Kuziv, M. I., 2013. Vahovyi ta liniinyi rist telyts ukrainskoi chorno-riaboi molochnoi porody v umovakh zakhidnoho rehionu Ukrainy [Weight and linear growth heifers Ukrainian Black and White dairy cattle in the western region of Ukraine]. Visnyk Sumskoho natsionalnoho ahrarnoho universytetu, no. 1, pp. 40-43.

13. Mankovskyi, A. la., 2009. Molochna produktyvnist pervistok zalezhno vid zhyvoi masy telyts ta viku otelennia [Dairy productivity of first-borns depending on the live weight of heifers and the age of calving]. Naukovyi visnyk natsionalnoho universytetu bioresursiv i pryrodokorystuvannia Ukrainy, issue 138, pp. 63-68.

14. Merkur'eva, E. K., 1977. Geneticheskie osnovy selektsii v skotovodstve [Genetic principles of selection in the livestock]. Moskva: Kolos.

15. Pidpala, T. V., Yasevin, S. le. and Drovniak, O. V., 2011. Intensyvne vyroshchuvannia remontnoho molodniaku molochnoi khudoby. Suchasni problemy selektsii, rozvedennia ta hihiieny tvaryn [Intensive rearing of repair young cattle. Modern problems of selection, breeding and hygiene of animals]. Zbirnyk naukovykh prats Vinnytskoho NAU, no. 11(51), pp.117-120.

16. Svechin, K. B., 1976. Individual'noe razvitie sel'skokhozyaystvennykh zhivotnykh [Individual development of farm animals]. K.: Urozhay.

17. Sermyagin, A. A., Filipchenko, A. A., Ermilov, A. N. and Yanchukov, I. N. 2018. Parametry rosta i razvitiya korov chernopestroy i golshtinskoy porod v svyazi s produktivnym dolgoletiem [Growth and development parameters of Black-and-White and Holstein cows in connection with productive longevity]. Dal'nevostochnyy agrarnyy vestnik, no. 4(48), pp. 194-202.

18. Sklyarenko, Yu. I., 2018. Vliyanie intensivnosti razvitiya telochek na ikh dal'neyshie khozyaystvenno-poleznye priznaki [Influence of the intensity of development of heifers on their further economically useful traits]. Nauchno-tekhnicheskiy byulleten' Instituta zhivotnovodstva Natsional'noy akademii agrarnykh nauk Ukrainy. no. 119, pp. 134-141.

19. Sklyarenko, Yu. I., Chernyavskaya, T. A. and Ivankova, I. P., 2017. Vliyanie intensivnosti razvitiya remontnykh telok ukrainskoy buroy molochnoy porody na produktivnost' korov-pervotelok. Integratsiya nauki i praktiki dlya razvitiya Agropromyshlennogo kompleksa [Influence of the intensity of development of replacement heifers of the Ukrainian brown dairy breed on the productivity of first-calf cows. Integration of science and practice for the development of the Agro-industrial complex.]. Sbornik statey Vserossiyskoy nauchnoy konferentsii, pp. 113-119.

20. Stadnytska, O. I., 2011. Vplyv rostu i rozvytku koriv u period vyroshchuvannia na yikh molochnu produktyvnist [Influence of growth and development of cows in the period of cultivation on their dairy productivity]. Rozvedennia $i$ henetyka tvaryn, issue 45 , pp. 264-270.

21. Tytarenko, I. V., Bushtruk, M. V. and Starostenko, I. S., 2016. Vplyv intensyvnosti vyroshchuvannia telyts na yikh vidtvornu zdatnist ta molochnu produktyvnist [The influence of the intensity of growing heifers on their reproductive capacity and milk productivity]. Naukovo-tekhnichnyi biuleten NDTs biobezpeky ta ekolohichnoho kontroliu resursiv APK, vol. 4, no. 1, pp. 260-266

22. Trotsenko, Z. H., 2010. Vplyv tempiv rozvytku remontnykh telyts ukrainskoi chorno-riaboi molochnoi porody na molochnu produktyvnist koriv-pervistok [Influence of rates of development of repair heifers of the Ukrainian Black-and-White dairy breed on milk productivity of first-born cows]. Visnyk Poltavskoi derzhavnoi ahrarnoi akademii, no. 2, pp. 79-81.

23. Khmelnychyi, L. M., 2012. Otsinka rostu ta rozvytku telyts ukrainskoi chervono-riaboi molochnoi porody za vykorystannia vahovykh ta liniinykh parametriv [Estimation of growth and development of heifers of the Ukrainian Red-and-White dairy breed with use of weight and linear parameters]. Visnyk Sumskoho natsionalnoho ahrarnoho universytetu, no. 12, pp. 18-21.

24. Shevchuk, B. I., 2016. Vliyanie vyrashchivaniya telok v molozivno-profilaktornyy i molochnyy periody na budushchuyu molochnuyu produktivnost' korov-pervotelok [Influence of rearing heifers in colostrum-prophylactic and milk periods on the future milk production of first-calf cows]. Nauchno-tekhnicheskiy byulleten' Instituta zhivotnovodstva Natsional'noy akademii agrarnykh nauk Ukrainy, no. 116, pp. 186-192.

25. Yushkova, I. V., Petrova, M. Yu. and Knyazeva, T. A., 2015. Parametry vyrashchivaniya remontnykh telok vnutriporodnykh tipov $v$ omskoy oblasti [Parameters of growing replacement heifers of intra-breed types in the Omsk region]. Genetika i razvedenie zhivotnykh, no. 2, pp. 12-15.

\section{Список використаної літератури:}

Вісник Сумського національного аграрного університету 
1. Буркат В.П., Мельник Ю.Ф., Єфіменко М.Я. та ін. Програми селекції порід. Розведення і генетика тварин. 2003. Вип. 37, С. 3-22.

2. Гиль М.І., Каратєєва О.І., Галушко І.А. Молочна продуктивність голштинських корів залежно від типу формування їх організму. «Молодий вчений». 2017. №5(45), С. 14-18.

3. Гордійчук Н.М., Півторак Я.І. Вплив живої маси теличок української червоно-рябої молочної породи при народженні на ріст і розвиток та молочну продуктивність. Збірник наукових праць Вінницького державного аграрного університету. 2008. Вип. 34. Т.3, С. 57-60.

4. Денисюк О.В. Вплив інтенсивності формування живої маси на молочну продуктивність корів. Розведення і генетика тварин. 2015. Вип. 49, С. 80-85.

5. Заблудовський Є.Є., Голубчик Ю.І. Реалізація продуктивного потенціалу молочної худоби у зв'язку з особливостями росту. Розведення і генетика тварин.: матеріали наукової дискусії "Розведення сільськогосподарських тварин за лініями" : міжвідомчий тематичний науковий збірник IPГТ. К. : Науковий світ, 2002. Вип. 36, С. 61-63.

6. Зубець М.В. Сірацький Й.З., Данилків Я.Н. Вирощування ремонтних телиць. К.: Урожай, 1993. - 136 с.

7. Зубець М.В., Буркат В.П., Єфіменко М.Я. та ін. Генетико-селекційний моніторинг у молочному скотарстві. за ред. В.П. Бурката. К.: Аграрна наука, 1999. 88 с.

8. Ивашков А.И., Рыжкова Л.Ю. Особенности роста высокопродуктивных коров. Вестник Российского государственного аграрного заочного университета. 2006. № 1. (6), С. 121-122.

9. Икоева Л.П., Хаева О.Э. Выращивание ремонтных телок черно-пестрой породы разного генотипа по голштинской породе. Известия Горского государственного аграрного университета. 2014. Т. 51. №3, С. 133-141.

10. Ілляшенко Г.Д. Зв'язок молочної продуктивності корів з живою масою і віком при першому осіменінні. Розведення і генетика тварин. 2017. Вип. 54, С. 45-50.

11. Кругляк О.В. Формування високопродуктивних молочних стад, як чинник підвищення ефективності виробництва молока. Економіка АПК, 2018, № 3, С. 24-31.

12. Кузів М.І. Ваговий та лінійний ріст телиць української чорно-рябої молочної породи в умовах західного регіону України. Вісник Сумського національного аграрного університету. 2013. №1, С. 40-43.

13. Маньковський А.Я. Молочна продуктивність первісток залежно від живої маси телиць та віку отелення. Науковий вісник національного університету біоресурсів і природокористування України. 2009. Вип. 138, С. 63-68.

14. Меркурьева Е. К. Генетические основы селекции в скотоводстве. М.: Колос, 1977. 240 с.

15. Підпала Т.В., Ясевін С.Є., Дровняк О.В. Інтенсивне вирощування ремонтного молодняку молочної худоби. Сучасні проблеми селекції, розведення та гігієни тварин. Збірник наукових праць Вінницького НАУ. 2011. № 11 (51), С.117-120.

16. Свечин К.Б. Индивидуальное развитие сельскохозяйственных животных. К.: Урожай, 1976. - 288 с.

17. Сермягин А.А., Филипченко А.А., Ермилов А.Н., Янчуков И.Н. Параметры роста и развития коров черно-пёстрой и голштинской пород в связи с продуктивным долголетием. Дальневосточный аграрный вестник. 2018. №4(48), С. 194-202.

18. Скляренко Ю.И. Влияние интенсивности развития телочек на их дальнейшие хозяйственно-полезные признаки. Научно-технический бюллетень Института животноводства Национальной академии аграрных наук Украины. 2018. №119, С. $134-141$.

19. Скляренко Ю.И., Чернявская Т.А., Иванкова И.П. Влияние интенсивности развития ремонтных телок украинской бурой молочной породы на продуктивность коров-первотелок. Интеграция науки и практики для развития Агропромышленного комплекса. Сборник статей Всероссийской научной конференции. 2017. С. 113-119.

20. Стадницька О.І. Вплив росту і розвитку корів у період вирощування на їх молочну продуктивність. Розведення і генетика тварин. 2011. Вип. 45, С. 264-270.

21. Титаренко І.В., Буштрук М.В., Старостенко І.С. Вплив інтенсивності вирощування телиць на їх відтворну здатність та молочну продуктивність. Науково-технічний бюлетень НДЦ біобезпеки та екологічного контролю ресурсів АПК. 2016. Т.4, №1, С. 260-266.

22. Троценко 3.Г. Вплив темпів розвитку ремонтних телиць української чорно-рябої молочної породи на молочну продуктивність корів-первісток. Вісник Полтавської державної аграрної академії. 2010. №2, С. 79-81.

23. Хмельничий Л.М. Оцінка росту та розвитку телиць української червоно-рябої молочної породи за використання вагових та лінійних параметрів. Вісник Сумського національного аграрного університету. 2012. №12, С. 18-21.

24. Шевчук Б.И. Влияние выращивания телок в молозивно-профилакторный и молочный периоды на будущую молочную продуктивность коров-первотелок. Научно-технический бюллетень Института животноводства Национальной академии аграрных наук Украины. 2016. №116, С. 186-192.

25. Юшкова И.В., Петрова М.Ю., Князева Т.А. Параметры выращивания ремонтных телок внутрипородных типов в омской области. Генетика и разведение животных. 2015. № 2. С. 12-15.

Хмельничий Сергій Леонтійович, кандидат сільськогосподарських наук, ст. викладач, Сумський національний аграрний університет (Суми, Україна)

Карпенко Богдан Миколайович, аспірант, Сумський національний аграрний університет (Суми, Україна)

Бардаш Дмитрій Олександрович, аспірант, Сумський національний аграрний університет (Суми, Україна)

Особливості розвитку ремонтних телиць українських червоно-рябої та чорно-рябої молочних порід у господарствах сумського регіону

У провідних господарствах Сумського регіону вивчалися особливості росту ремонтних телиць українських чорно- 
рябої (ПЗ ПП “Буринське”) та червоно-рябої (ТОВ «Млинівський комплекс») молочних порід. Досліджували абсолютні та відносні показники приростів живої маси телиць у віковій динаміці від народження до 18-ти місячного віку. Кращими за живою масою при народженні виявились телички української червоно-рябої молочної породи (36,2 ка) у порівнянні із ровесницями української чорно-рябої молочної (33,9 ке). Їхня перевага збереглася упродовж 18-ти місячного періоду вирощування. Ремонтні телиці української червоно-рябої молочної породи на заключному етапі розвитку з середньою живою масою 414,2 кट перевищували одноліток української чорно-рябої молочної з високодостовірною різницею на 15,5 к己 (P<0,001). Розвиток ремонтних телиць обох порід у межах отриманих показників живої маси забезпечив їхній приріст на час парувального віку на рівні 76-80\% від мінімальних иільових стандартів, визначених на перспективу для корів-первісток молочного типу створених порід. Середньодобові прирости живої маси у молочний період склали у теличок української чорнорябої молочної породи в середньому 810,4 г, а у їхніх ровесниць української червоно-рябої - 847,3 г. Після шестимісячного періоду вирощування і до парувального віку різниця за середньодобовими приростами була вищою у тварин української червоно-рябої молочної породи стада ТОВ «Млинівський комплекс». Результати досліджень засвідчили, що за створення відповідних умов годівлі та утримання ремонтні телиці українських чорно-рябої та червоно-рябої молочних порід здатні до високої інтенсивності росту.

Ключові слова: українська чорно-ряба, українська червоно-ряба, ремонтні телиці, жива маса.

Дата надходження до редакції: 04.09.2020 р. 